\title{
PENGARUH KOMPRES AIR HANGAT DAN AIR DINGIN TERHADAP NYERI TULANG BELAKANG IBU HAMIL TRIMESTER III DI WILAYAH KERJA PUSKESMAS RAJAPOLAH TAHUN 2018
}

\author{
OLEH \\ Aulia, Nunung Mulyani, Uly Artha Silalahi
}

\begin{abstract}
Penatalaksanaannyeripadapunggung saat kehamilan bervariatif seperti penatalaksanaan farmakologimaupunnon farmakologis, Efek fisiologis kompres hangat dapat meredakan nyeri dengan merileksasi otot, memiliki efek sedatif dan meredakan nyeri dan kompres dingin dapat membuat area menjadi mati rasa, memperlambat kecepatan hantaran syaraf sehingga memperlambat aliran impuls nyeri. Tujuan dalam penelitian ini adalah untuk membandingkan tingkat nyeri punggung ibu hamil trimester 3 setelah dilakukan kompres air hangat dan air dingin.

Metode penelitian yang digunakan adalah quasi eksperimen tipe non-equivalent control group design. Sampel pada penelitian ini adalah ibu hamil trimester 3 yang memeriksakan kandungannya di wilayah kerja Puskesmas Rajapolah dan mengeluh sakit punggung dengan teknik accidental sampling jumlah sampel sebesar 56 orang.

Hasil penelitian menunjukkan bahwa nilai intensitas nyeri punggung pada perlakukan kompres hangat sebesar 1.61 sementara intensitas nyeri punggung pada perlakukan kompres dingin sebesar 0.57. Maka dapat diambil kesimpulan bahwa kompres dingin lebih baik dibandingkan dengan kompres hangat karena nilai ratarata turunnya rasa sakit pada punggung sebesar 0.57 .

Kesimpulannya yaitu ada perbedaan tingkat nyeri sebelum dan setelah dilakukan kompres air hangat dan dingin di Wilayah Kerja Puskesmas Rajapolah, dan kompres dingin lebih baik dalam penurunan nyerinya dibandingkan dengan kompres hangat.

Sarannya agar kompres dingin ini dapat diterapkan dan diajarkan kepada ibu hamil sehingga dapat membantu ibu dalam mengatasi nyeri punggungnya
\end{abstract}
Kata Kunci
: kompres hangat, kompres dingin, nyeri punggung
Kepustakaan
: $(2006-2017)$ 


\section{A. LATAR BELAKANG}

Kehamilan adalah peristiwa yang didahului dengan bertemunya sel telur atau ovum dengan sel sperma. Proses kehamilan akan berlangsung selama kira-kira 10 bulan, atau 9 bulan kalender, atau 40 minggu, atau 280 hari yang dihitung dari hari pertama periode menstruasi terakhir (Wagiyo dan Putrono, 2016). Varney dan Prawirohardjo (2008) mengemukakan bahwa selama masa kehamilan, banyak wanita mengalami perubahan psikologis dan emosional.

Ketidaknyamanan merupakan suatu perasaan yang kurang ataupun yang tidak menyenangkan bagi kondisi fisik ataupun mental pada ibu hamil. Kehamilan merupakan proses alamiah pada wanita yang akan menimbulkan berbagai perubahan dan menyebabkan rasa tidak nyaman, hal ini merupakan kondisi yang normal pada wanita hamil. Beberapa ibu biasanya mengeluh mengenai hal-hal yang membuat kehamilanya tidak nyaman dan kadang menyulitkan ibu (Hidayat, 2008: 120).

Ibu hamil trimester III seringkali mengalami keluhan nyeri punggung, hal ini menjadi salah satu penyebab ketidaknyamanan trimester III. Nyeri punggung merupakan nyeri yang terjadi pada area lumbosakral. Nyeri punggung akan meningkat intensitasnya seiring pertambahan usia kehamilan karena nyeri ini merupakan akibat pergeseran pusat gravitasi dan perubahan postur tubuhnya (Varney, 2012).

Pada ibu hamil, postur tubuh berubah, bahu tertarik kebelakang sebagai akibat pembesaran abdomen yang menonjol, dan untuk mempertahankan keseimbangan tubuh, kelengkungan tulang belakang ke arah

dalam menjadi berlebihan. Relaksasi sendi sakroiliaka, yang mengiringi perubahan postur, menyebabkan peningkatan nyeri punggung (Tiran, 2008).

Nyeri punggung saat ibu hamil apabila tidak ditangani dengan baik dapat menyebabkan kualitas hidup ibu hamil menjadi buruk. Gejala nyeri punggung ini juga disebabkan oleh hormon estrogen dan progesteron yang mengendurkan sendi, ikatan tulang dan otot dipinggul (Tiran, 2008).

Penatalaksanaan nyeri pada punggung saat kehamilan bervariatif seperti penatalaksanaan farmakologi maupun non farmakologis. Pemberian analgetik seperti paracetamol, NSAID, dan ibupropen termasuk penatalaksanaan nyeri secara farmakologis, sedangkan penatalaksanaan non-farmakologis meliputi manual terapi seperti pijat dan latihan mobilisasi, akupuntur, relaksasi, terapi air hangat dan air dingin (Potter dan Perry, 2011 dalam IASP , 2009).

Efek fisiologis kompres panas adalah bersifat vasodilatasi, meredakan nyeri dengan merileksasi otot, memiliki efek sedatif dan meredakan nyeri dengan menyingkirkan produk-produk inflamasi yang menimbulkan nyeri. Efek fisiologis kompres dingin adalah bersifat vasokontriksi, membuat area menjadi mati rasa, memperlambat kecepatan hantaran syaraf sehingga memperlambat aliran impuls nyeri.

Hasil penelitian didapatkan bahwa prevalensi terjadinya nyeri

punggung pada ibu hamil trimester III menurut survey yang dilakukan di Inggris dan Skandinavia, terdapat 50\% 
ibu hamil trimester III mengalami nyeri punggung (Diane M Fraser, 2009 dalam Ummah, 2012).

Berdasarkan survey yang dilaksanakan oleh University of Ulster 2014, didapatkan hasil bahwa dari 157 orang hamil trimester III yang mengisi kuesioner, $70 \%$ diantaranya pernah mengalami nyeri punggung, dikutip dalam Hakiki (2015).

Berdasarkan studi pendahuluan yang dilakukan pada tanggal 21 Desember 2015 sampai dengan tanggal 2 Januari 2016 di Bidan Praktek Swasta Furida Azis, didapatkan hasil bahwa dari 10 ibu hamil trimester III, 70\% ibu hamil mengalami nyeri punggung dengan intensitas nyeri 6-7. Hasil dari penelitian pada ibu hamil di berbagai wilayah Indonesia mencapai $60-80 \%$ ibu hamil mengalami nyeri punggung pada kehamilannya (Mafikasari dan Kartikasari, 2015).

Berdasarkan survey awal peneliti yang dilakukan di wilayah kerja Puskesmas Rajapolah pada tanggal 10 sampai dengan tanggal 15 November 2017, diperoleh hasil bahwa dari 5 orang ibu hamil trimester III yang memeriksakan kandungannya ke bidan, 4 orang ibu hamil diantaranya mengeluh nyeri pinggang (tulang belakang bagian bawah).Berdasarkan latar belakang diatas, maka peneliti tertarik untuk melakukan penelitian yang berjudul "Pengaruh Kompres Air Hangat dan Air Dingin Terhadap Nyeri Tulang Belakang Ibu Hamil Trimester III di Wilayah Kerja Puskesmas Rajapolah Tahun 2018”.

\section{B. METODE PENELITIAN}

Penelitian ini merupakan penelitian quasi eksperimen tipe non-equivalent control group design, yaitu melibatkan lebih dari satu variabel independent (bebas), perlakuan dilakukan pada lebih dari satu kelompok dengan bentuk perlakuan yang berbeda. Tujuan dari penelitian ini untuk mengetahui suatu gejala atau pengaruh yang timbul sebagai akibat dari adanya perlakuan tertentu (Notoatmodjo, 2010).

Sample merupakan bagian populasi yang merepresentasikan dari karakteristik populasi. Sampel adalah sebagian dari populasi, yang merupakan "perwakilan" dari populasi (Hamidi, 2007).

Sampel pada penelitian ini berjumlah 56 orang ibu hamil trimester III yang memeriksakan kandungannya di wilayah kerja Puskesmas Rajapolah dan mengeluh sakit punggung, dengan rincian 28 orang yang dilakukan kompres air hangat dan 28 orang yang dilakukan kompres air dingin. 


\section{HASIL PENELITIAN}

1. Gambaran tingkat nyeri ibu hamil trimester III sebelum dan sesudah dilakukan kompres air hangat di Wilayah Kerja Puskesmas Rajapolah

Tabel 1

Distribusi Frekuensi tingkat nyeri tulang belakang ibu hamil trimester III sebelum dan sesudah dilakukan kompres air hangat di Wilayah Kerja Puskesmas Rajapolah Tahun 2018

\begin{tabular}{|c|c|c|c|c|c|c|}
\hline Intensitas Nyeri & $\mathbf{N}$ & $\begin{array}{c}\text { Rata- } \\
\text { rata }\end{array}$ & Min & Max & SD & $\mathbf{P}^{*}$ \\
\hline Sebelum & 28 & 5.035 & 2 & 7 & 1.52 & 0.547 \\
\hline Sesudah & 28 & 1.607 & 0 & 5 & 1.25 & 0.219 \\
\hline
\end{tabular}

Dari tabel 1 menunjukkan bahwa gambaran tingkat nyeri ibu hamil trimester III sebelum di lakukan kompres hangat rata-rata nyeri punggung pada ibu hamil adalah 5.035, dengan nilai terkecil sebesar 2 dan terbesar sebesar 7 dengan standar deviasi sebesar 1.52 dan data dinyatakan normal dengan nilai $\mathrm{P}=0.547$ hal ini dikarenakan nilai $\mathrm{P}>0.05$. Setelah dilakukan kompres hangat rata-rata nyeri punggung pada ibu hamil adalah 1.607, dengan nilai terkecil sebesar 0 dan terbesar sebesar 5 dengan standar deviasi sebesar 1.25 dan data dinyatakan normal dengan nilai $\mathrm{P}=0.219$, hal ini dikarenakan nilai $\mathrm{P}>0.05$.

\section{Gambaran tingkat nyeri ibu hamil trimester III sebelum dan sesudah dilakukan kompres air dingin di Wilayah Kerja Puskesmas Rajapolah}

Hasil penelitian mengenai gambaran tingkat nyeri ibu hamil trimester III sebelum dan sesudah dilakukan kompres air dingin di Wilayah Kerja Puskesmas Rajapolah dapat dilihat pada tabel di bawah ini:

Tabel 2

Distribusi Frekuensi tingkat nyeri tulang belakang ibu hamil trimester 3 sebelum dan sesudah dilakukan kompres air dingin di Wilayah Kerja Puskesmas Rajapolah Tahun 2018

\begin{tabular}{|c|c|c|c|c|c|c|}
\hline Intensitas Nyeri & $\mathbf{N}$ & $\begin{array}{c}\text { Rata- } \\
\text { rata }\end{array}$ & Min & Max & SD & $\mathbf{P}^{*}$ \\
\hline Sebelum & 28 & 5.464 & 3 & 8 & 1.290 & 0.219 \\
\hline Sesudah & 28 & 0.571 & 0 & 3 & 0.790 & 0.104 \\
\hline
\end{tabular}

Dari tabel 2 menunjukkan bahwa gambaran tingkat nyeri ibu hamil trimester 3 sebelum di lakukan kompres hangat rata-rata nyeri punggung pada ibu hamil adalah 5.464, dengan nilai terkecil sebesar 3 dan terbesar sebesar 8 dengan standar deviasi sebesar 1.290 dan data dinyatakan normal dengan nilai $\mathrm{P}=0.219$ hal ini dikarenakan nilai $\mathrm{P}>0.05$. Setelah dilakukan kompres hangat rata-rata nyeri punggung pada ibu hamil adalah 0.571 , dengan nilai terkecil sebesar 0 dan terbesar 
sebesar 3 dengan standar deviasi sebesar 0.790 dan data dinyatakan normal dengan nilai $\mathrm{P}=0.104$, hal ini dikarenakan nilai $\mathrm{P}>0.05$.

3. Analisis Bivariat

a. Perbandingan tingkat nyeri ibu hamil trimester III sebelum dan sesudah dilakukan kompres air hangat di Wilayah Kerja Puskesmas Rajapolah

Berdasarkan hasil diperoleh bahwa perbandingan tingkat nyeri ibu hamil trimester III sebelum dan sesudah dilakukan kompres air hangat menggunakan uji t.

Tabel 3

Perbandingan tingkat nyeri tulang belakang ibu hamil trimester III sebelum dan sesudah dilakukan kompres air hangat di Wilayah Kerja Puskesmas Rajapolah Tahun 2018

\begin{tabular}{|l|c|c|c|}
\hline \multicolumn{1}{|c|}{ Kompres } & Tingkat nyeri & t test & $\rho_{\text {value }}$ \\
\cline { 1 - 2 } Sebelum Kompres hangat & 5.035 & \multirow{2}{*}{14.400} & \multirow{2}{*}{0.001} \\
\cline { 1 - 2 } Setelah Kompres hangat & 1.6071 & & \\
\hline
\end{tabular}

Berdasarkan hasil uji statistik dengan menggunakan t-test diperoleh nilai t hitung sebesar 14.400 dengan $\rho$ value sebesar 0.001. Dengan demikian dapat disimpulkan $\mathrm{H}_{\mathrm{o}}$ ditolak dan $\mathrm{H}_{\mathrm{a}}$ diterima yang artinya ada perbedaan tingkat nyeri sebelum dan setelah dilakukan kompres air hangat di Wilayah Kerja Puskesmas Rajapolah.

b. Perbandingan tingkat nyeri ibu hamil trimester III sebelum dan sesudah dilakukan kompres air dingin di Wilayah Kerja Puskesmas Rajapolah

Berdasarkan hasil diperoleh bahwa perbandingan tingkat nyeri ibu hamil trimester III sebelum dan sesudah dilakukan kompres air dingin menggunakan uji t.

\section{Tabel 4}

Perbandingan tingkat nyeri tulang belakang ibu hamil trimester III sebelum dan sesudah dilakukan kompres air dingin di Wilayah Kerja Puskesmas Rajapolah Tahun 2018

\begin{tabular}{|l|c|c|c|}
\hline \multicolumn{1}{|c|}{ Kompres } & Tingkat nyeri & t test & $\rho_{\text {value }}$ \\
\cline { 1 - 2 } Sebelum Kompres dingin & 5.464 & \multirow{2}{*}{18.193} & 0.001 \\
\hline Setelah Kompres dingin & 0.571 & & \\
\hline
\end{tabular}

Berdasarkan hasil uji statistik dengan menggunakan t-test diperoleh nilai $\mathrm{t}$ hitung sebesar 18.193 dengan $\rho$ value sebesar 0.001. Dengan demikian dapat disimpulkan $\mathrm{H}_{\mathrm{o}}$ ditolak dan $\mathrm{H}_{\mathrm{a}}$ diterima yang artinya ada perbedaan tingkat nyeri sebelum dan setelah dilakukan kompres air dingin di Wilayah Kerja Puskesmas Rajapolah. 
c. Perbandingan tingkat nyeri ibu hamil trimester III sesudah dilakukan kompres air hangat dan air dingin di Wilayah Kerja Puskesmas Rajapolah

Berdasarkan hasil diperoleh bahwa tingkat nyeri ibu hamil trimester III sesudah dilakukan kompres air hangat dan air dingin di Wilayah Kerja Puskesmas Rajapolah menggunakan uji t.

Tabel 5

Perbandingan tingkat nyeri tulang belakang ibu hamil trimester III sesudah dilakukan kompres air hangat dan air dingin di Wilayah Kerja Puskesmas Rajapolah Tahun 2018

\begin{tabular}{|l|c|c|c|}
\hline \multicolumn{1}{|c|}{ Kompres } & Tingkat nyeri & t test & $\rho_{\text {value }}$ \\
\hline Kompres hangat & 1.6071 & \multirow{2}{*}{4.345} & 0.001 \\
\cline { 1 - 2 } Kompres dingin & 0.5714 & & \\
\hline
\end{tabular}

Berdasarkan hasil uji statistik dengan menggunakan $t$ test diperoleh nilai $\mathrm{t}$ hitung sebesar 14.400 dengan $\rho$ value sebesar 0.001. Dengan demikian dapat disimpulkan $\mathrm{H}_{\mathrm{o}}$ ditolak dan $\mathrm{H}_{\mathrm{a}}$ diterima yang artinya ada perbedaan tingkat nyeri setelah dilakukan kompres air hangat dan air dingin di Wilayah Kerja Puskesmas Rajapolah.

\section{PEMBAHASAN}

1. Tingkat nyeri tulang belakang ibu hamil trimester III sebelum dan sesudah dilakukan kompres air hangat di Wilayah Kerja Puskesmas Rajapolah

Hasil penelitian yang telah dideskripsikan di atas diperoleh bahwa gambaran tingkat nyeri ibu hamil trimester III sebelum dan sesudah dilakukan kompres air hangat di Wilayah Kerja Puskesmas Rajapolah, pada kondisi sebelum di lakukan kompres hangat rata-rata nyeri punggung pada ibu hamil adalah 5.035, dengan nilai terkecil sebesar 2 dan terbesar sebesar 7 dengan standar deviasi sebesar 1.52 dan data dinyatakan normal dengan nilai $\mathrm{P}=0.547$ hal ini dikarenakan nilai $\mathrm{P}>0.05$. Serta setelah dilakukan kompres hangat rata-rata nyeri punggung pada ibu hamil adalah 1.607, dengan nilai terkecil sebesar 0 dan terbesar sebesar 5 dengan standar deviasi sebesar 1.25 dan data dinyatakan normal dengan nilai $\mathrm{P}=0.219$, hal ini dikarenakan nilai $\mathrm{P}>0.05$. Nilai penurunan nyeri dengan sebelum dan setelah kompres dingin yaitu $5.035-1.607$ $=3.428$

Hal ini dikarenakan dengan pemberian kompres hangat menggunakan kantung berisi air hangat dengan suhu $46^{\circ} \mathrm{C}$ dapat melunakkan jaringan fibrosa dan membuat otot lebih rileks, sehingga dapat menurunkan rasa nyeri dan memperlancar pasokan aliran darah dan memberikan ketenangan pada pasien (Ihina Angelina, 2013). Sesuai dengan hasil temuan dalam penelitian, bahwa pada saat pemberian kompres hangat pada 
daerah nyeri selama 15 menit klien merasa lebih nyaman dan rileks.

Hal tersebut didukung oleh Yuni Kusmiati, (2009) mengatakan bahwa kompres hangat yang digunakan berfungsi untuk melebarkan pembuluh darah, menstimulasi sirkulasi darah, dan mengurangi kekakuan. Selain itu, kompres hangat juga berfungsi menghilangkan sensasi rasa sakit. Untuk mendapatkan hasil yang terbaik, terapi kompres hangat dilakukan selama 15 menit dengan 1 kali pemberian dan pengukuran intensitas nyeri dilakukan segera setelah tindakan kompres dilakukan.

Hal ini didukung pula oleh penelitian yang serupa seperti yang dilakukan oleh Sani Abdullah (2013) dari 40 responden yang dibagi dalam dua kelompok intervensi, kelompok yang pertama dilakukan pemberian intervensi kompres hangat sedangkan kelompok kedua dilakukan intervensi kompres dingin menghasilkan kesimpulan bahwa rata-rata penurunan skala nyeri pada kompres hangat adalah 1,60

Berdasarkan hasil penelitian dengan teori penelitian sejalan dan menyatakan bahwa dengan tindakan kompres hangat dapat menurunkan respons nyeri ibu dikarenakan ibu merasa nyaman dengan rasa yang ditimbulkan saat dilakukannya kompres hangat pada daerah nyeri.

2. Gambaran tingkat nyeri tulang belakang ibu hamil trimester III sebelum sebelum dan sesudah dilakukan kompres air dingin

Hasil penelitian diperoleh bahwa gambaran tingkat nyeri ibu hamil trimester III sebelum dan sesudah dilakukan kompres air dingin di
Wilayah Kerja Puskesmas Rajapolah, pada kondisi sebelum di lakukan kompres hangat rata-rata nyeri punggung pada ibu hamil adalah 5.464, dengan nilai terkecil sebesar 3 dan terbesar sebesar 8 dengan standar deviasi sebesar 1.290 dan data dinyatakan normal dengan nilai $\mathrm{P}=0.219$ hal ini dikarenakan nilai $\mathrm{P}>0.05$. Serta setelah dilakukan kompres hangat rata-rata nyeri punggung pada ibu hamil adalah 0.571 , dengan nilai terkecil sebesar 0 dan terbesar sebesar 3 dengan standar deviasi sebesar 0.790 dan data dinyatakan normal dengan nilai $\mathrm{P}=0.104$, hal ini dikarenakan nilai $\mathrm{P}>0.05$. Nilai penurunan nyeri dengan sebelum dan setelah kompres dingin yaitu $5.464-0.104$ $=5.36$.

Hal ini sejalan dengan teori dari Uliyah\&Hidayat, (2008) mengatakan bahwa manfaat dari kompres dingin ini adalah kompres dingin pada bagian tubuh akan menyerap panas dari area tersebut, mencegah peradangan meluas, mengurangi perdarahan setempat, mengurangi rasa sakit pada daerah setempat, menyebabkan pengecilan pembuluh darah (Vasokonstriksi), mengurangi oedema dengan mengurangi aliran darah ke area.

Serta (Franser, 2009) Mengatakan bahwa kompres dingin adalah suatu metode dalam penggunaan suhu rendah setempat yang dapat menimbulkan beberapa efek fisiologis. Aplikasi kompres dingin adalah mengurangi aliran darah ke suatu bagian dan mengurangi perdarahan serta edema. Diperkirakan bahwa terapi dingin menimbulkan efek analgetik dengan 
memperlambat kecepatan hantaran saraf sehingga impuls nyeri yang mencapai otak lebih sedikit. Mekanisme lain yang mungkin bekerja adalah bahwa persepsi dingin menjadi dominan dan mengurangi persepsi nyeri.

Tujuan dalam pengobatan nyeri adalah mengurangi nyeri sebesar mungkin dengan efek samping paling kecil (Chapman, 2006). Hal ini sesuai dengan teori Musrifatul $\mathrm{M}$ dan Alimul, bahwa kompres dingin dapat memberikan relaksasi pada otot yang tegang dan kekakuan sendi.

Berdasarkan uraian tersebut di atas dapat disimpulkan bahwa dengan kegiatan kompres dingin pada ibu hamil trimester III dapat membantu meringankan rasa nyeri yang dialami ibu.

\section{a. Perbandingan tingkat nyeri punggung ibu hamil trimester III setelah dilakukan kompres air hangat dan air dingin}

Hasil penelitian menunjukkan bahwa tingkat nyeri punggung ibu hamil trimester III setelah dilakukan kompres air hangat adalah 1.6071 dan setelah dilakukan kompres dingin adalah sebesar 0.571, berdasarkan uraian diatas dapat disimpulkan bahwa dengan kompres dingin lebih kecil skor skala nyerinya dibandingkan dengan kompres hangat. Jadi dapat disimpulkan bahwa kompres dingin lebih baik dibandingkan dengan kompres hangat.

Berdasarkan hasil uji statistik dengan menggunakan $t$ test diperoleh nilai $t$ hitung sebesar 14.400 dengan $\rho$ value sebesar
0.001. Dengan demikian dapat disimpulkan $\mathrm{H}_{\mathrm{o}}$ ditolak dan $\mathrm{H}_{\mathrm{a}}$ diterima yang artinya ada perbedaan pengaruh kompres air hangat dan air dingin terhadap tingkat nyeri tulang balakang ibu hamil trimester III di wilayah kerja Puskesmas Rajapolah.

Hal ini dikarenakan bahwa kompres dingin efektif dalam menurunkan nyeri hal ini dikarenakan kompres hangat dan kompres dingin tertuju pada rasa nyerinya serta dapat dilakukan oleh sendiri/keluarga dan dapat merangsang ibu agar relaks untuk dapat mengalihkan rasa nyeri yang dialaminya.

Menurut (Fathia, 2013) Kompres hangat berfungsi meningkatkan aliran darah sehingga mempercepat penyembuhan, meningkatkan aliran kelenjar getah bening untuk membuang zat-zat yang tidak diperlukan oleh tubuh. kompres hangat juga berfungsi menurunkan nyeri dengan cara yang sama dengan kompres dingin, yaitu memblokade sensasi nyeri. Sensasi hangat juga membuat rileks tubuh sehingga mengurangi kekakuan otot dan sendi dan Kompres dingin adalah suatu metode dalam penggunaan suhu rendah setempat yang dapat menimbulkan beberapa efek fisiologis. Aplikasi kompres dingin adalah mengurangi aliran darah ke suatu bagian dan mengurangi perdarahan serta edema.

Hal ini sejalan dengan hasil penelitian Mutia Felina (2015) dengan judul Pengaruh Kompres Panas dan Dingin terhadap Penurunan Nyeri Kala I Fase Aktif Persalinan Fisiologis Ibu Primipara, hasil penelitian menunjukkan bahwa terdapat perbedaan pengaruh 
pemberian kompres panas dan dingin terhadap penurunan nyeri persalinan

Dan hasil penelitian Gayatri Oktasari (2014) dengan judul Perbandingan Efektivitas Kompres Hangat Dan Kompres dingin Terhadap Penurunan Dismenorea pada Remaja Putri, hasil penelitian menunjukkan bahwa terdapat perbedaan yang signifikan antara kompres hangat dan kompres dingin terhadap penurunan dismenorea. Perbandingan Mean rank yang didapat antara perubahan intensitas nyeri pada kelompok kompres dingin lebih besar dibandingkan kelompok kompres hangat. Oleh karena itu kompres dingin lebih efektif dibanding kompres hangat.

\section{E. KESIMPULAN DAN SARAN}

Berdasarkan hasil penelitian dan pembahasan dapat disimpulkan bahwa :

1. Gambaran tingkat nyeri ibu hamil trimester III sebelum dan sesudah dilakukan kompres air hangat di Wilayah Kerja Puskesmas Rajapolah, sebelum di lakukan kompres air hangat ratarata nyeri punggung pada ibu hamil adalah 5.035. Setelah dilakukan kompres air hangat ratarata nyeri punggung pada ibu hamil adalah 1.607 .

2. Gambaran tingkat nyeri ibu hamil trimester III sebelum dan sesudah dilakukan kompres air dingin di Wilayah Kerja Puskesmas Rajapolah, sebelum di lakukan kompres air dingin rata-rata nyeri punggung pada ibu hamil adalah 5.464. Setelah dilakukan kompres air dingin rata-rata nyeri punggung pada ibu hamil adalah 0.571 .

3. Ada perbedaan tingkat nyeri sebelum dan setelah dilakukan kompres air hangat di Wilayah Kerja Puskesmas Rajapolah, dengan $\rho$ value sebesar 0.001. Dengan demikian dapat disimpulkan $\mathrm{H}_{\mathrm{o}}$ ditolak dan $\mathrm{H}_{\mathrm{a}}$ diterima dan kompres dingin lebih baik dalam penurunan nyerinya dibandingkan dengan kompres hangat.

Berdasarkan hasil penelitian penulis mempunyai beberapa saran yaitu:

1. Bagi Puskesmas

Diharapkan dapat terus meningkatkan pelayanan kesehatan dengan merekomendasikan pelaksanaan kompres air dingin untuk dapat menurunkan nyeri tulang belakang pada ibu hamil trimester III.

\section{Bagi Bidan}

Bidan dalam melakukan asuhan pada ibu hamil trimester III dengan keluhan nyeri tulang belakang dapat menggunakan teknik kompres dingin.

3. Bagi Ibu Hamil

Hasil penelitian ini dapat menjadi solusi bagi ibu hamil untuk mengatasi nyeri tulang belakang melalui pelaksanaan kompres air dingin. 


\section{F. REFERENSI}

Abdullah, Sani. 2013. Inovasi Pembelajaran. Jakarta: Bumi Aksara Angelina, Ihina. 2013. Kompres Panas dan Dingin. Tersedia dalam http://lhinangelina.blogspot.co.id/2 013/04/makalah-kompres-panasdan-dingin.html diakses pada tanggal 20 November 2017.

Chapman, V. 2006. Asuhan Kebidanan Persalinan dan Kelahiran. Jakarta: EGC

Fathia. 2013. Pengaruh Pemberian Kompres Hangat Rebusan Parutan Jahe Terhadap Nyeri pada Lnsia dengan Osteoartritis

Felina, Mutia, dkk 2015. Pengaruh Kompres Panas dan Dingin terhadap Penurunan Nyeri Kala I Fase Aktif Persalinan Fisiologis Ibu Primipara

Fraser, Diane M. 2009. Myles Buku Ajar Bidan. Jakarta: Buku Kedokteran EGC

Hakiki,I.2015.

EfektifitasTerapiAirHangatTerhadap NyeriTulang BelakangPada IbuHamil

DiWilayahKerjaPuskesmas PisanganMahasiswaPSIK UIN Syarif HidayatullahJakarta.

Hamidi. 2007. Metodologi. Penelitian dan Teori Komunikasi. Malang: UMM
Hasan, Ikbal 2006. Analisis Data Penelitian Dengan Statistik. Jakarta: PT. Bumi.

Hidayat A, 2007. Metode Penelitian Keperawatan. Yogyakarta: Yayasan Penerbitan. Hidayat,MdanUliyah,M.2008.

KeterampilanDasar Praktik Klinik untuk

Kebidanan.Jakarta:SalembaMedika.

Kusmiyati, Yuni. 2009. Perawatan Ibu Hamil. Yogyakarta: Fitramaya

Mafikasari,A.,Kartikasari,R.I.201 5.PosisiTidurDenganKejadianBack

Notoatmodjo, S. 2010. Metodologi Penelitian Kesehatan. Jakarta: Rineka

Oktasari, Gayatri. 2014. Perbandingan Efektifitas Kompres Hangat dan Kompres Dingin terhadap Penurunan Dismenorea pada Remaja Putri

Potter, Perry. 2011. Buku Ajar Fundamental Keperawatan. Jakarta: Salemba Medika

Varney,Helen, (2008).Buku Asuhan kebidanan,volume, Edisi 4.Jakarta: EGC.

Wagiyo, Putrono. 2016. Asuhan Keperawatan Antenatal, Intranatal dan Bayi Baru Lahir Fisiologis dan Patologis. Jakarta: Andi 